\title{
On the exportability of the Dutch pension system to the European Union
}

Citation for published version (APA):

Sleijpen, O. C. H. M. (2009). On the exportability of the Dutch pension system to the European Union. Maastricht University. https://doi.org/10.26481/spe.20090206os

Document status and date:

Published: 06/02/2009

DOI:

10.26481/spe.20090206os

Document Version:

Publisher's PDF, also known as Version of record

\section{Please check the document version of this publication:}

- A submitted manuscript is the version of the article upon submission and before peer-review. There can be important differences between the submitted version and the official published version of record.

People interested in the research are advised to contact the author for the final version of the publication, or visit the DOI to the publisher's website.

- The final author version and the galley proof are versions of the publication after peer review.

- The final published version features the final layout of the paper including the volume, issue and page numbers.

Link to publication

\footnotetext{
General rights rights.

- You may freely distribute the URL identifying the publication in the public portal. please follow below link for the End User Agreement:

www.umlib.nl/taverne-license

Take down policy

If you believe that this document breaches copyright please contact us at:

repository@maastrichtuniversity.nl

providing details and we will investigate your claim.
}

Copyright and moral rights for the publications made accessible in the public portal are retained by the authors and/or other copyright owners and it is a condition of accessing publications that users recognise and abide by the legal requirements associated with these

- Users may download and print one copy of any publication from the public portal for the purpose of private study or research.

- You may not further distribute the material or use it for any profit-making activity or commercial gain

If the publication is distributed under the terms of Article $25 \mathrm{fa}$ of the Dutch Copyright Act, indicated by the "Taverne" license above, 
On the exportability of the Dutch pension system to the European Union 


\section{Colofon}

Ontwerp en print: Océ Business Services, Maastricht

ISBN: 978-90-5681-316-1

NUR: 784

Alle rechten voorbehouden. Niets uit deze uitgave mag worden verveelvoudigd, opgeslagen in een geautomatiseerd gegevensbestand of openbaar gemaakt worden, zonder voorafgaande schriftelijke toestemming van de auteur of uitgever. 


\section{On the exportability of the Dutch pension system to the European Union}

delivered in Dutch, in an abridged form, on accepting the position of Professor of European Economic Policy at the Faculty of Economics and Business Administration at Maastricht University,

Maastricht, 6 February 2009

Dr. Olaf C.H.M. Sleijpen 
Rector Magnificus, Ladies and gentlemen,

\section{Introduction}

In 2007 a number of organisations teamed up to establish Holland Financial Centre (HFC), a foundation that aims to promote the Dutch financial sector'. One of its key objectives is the promotion - in particular abroad - of pensions and retirement management as one of the corner stones of the Dutch financial industry. The initiatives of HFC are in the vein of similar programmes launched in Ireland, Belgium and Luxembourg.

The efforts of HFC raise a number of questions. First, what are the unique selling points of the Dutch pension system that make pensions a product worthwhile exporting abroad? Second, HFC was established before the financial "tsunami" hit the shores of our economy. Should exporting the Dutch pension system still be a priority under the current circumstances, as also questioned by De Nederlandsche Bank²? Third, if the business concept to be exported is clear, which countries' grounds are most fertile for the Dutch model?

All these questions will be addressed in this lecture. As the focus of my chair is on European economic policy, I will in particular discuss the exportability or transferability of the Dutch pension system to the countries of the European Union (EU). Indeed, there is a growing need for reform of pension systems in the EU, against the background of an ageing population and the lack of funded pension schemes in many EU Member States (European Commission, 2006).

\footnotetext{
Stichting HFC was founded by the Ministry of Finance, De Brauw Blackstone Westbroek, Robeco, Euronext, ING Group, Aegon, Rabobank, Kas Bank, ABN AMRO, De Nederlandsche Bank, Stichting Pensioenfonds ABP, Shell Asset Management, KPMG, Fortis, Loyens en Loeff, Nauta Dutilh, Deloitte, IMC, Eureko, Van der Moolen, Stichting Pensioenfonds PGGM, MN Services, Stichting Philips Pensioenfonds, Allen \& Overy, Delta Lloyd, Optiver, SNS Reaal, Ministry of Social Affairs and Employment, Stibbe, PriceWaterhouseCoopers, Ernst \& Young, Cordares, Stichting Unilever Pensioenfonds, Ministry of Economic Affairs and the Ministry of Justice.

2 "Nederland als financieel centrum", speech delivered by A.J. Kellermann, member of the Executive Board of De Nederlandsche Bank N.V., on 4 December 2008.
} 
It is important to note that-in the context of this lecture - the exportability of the Dutch pension system refers to funded pension arrangements, and notably the so-called second pillar schemes. Indeed, exportability of the Dutch system is intrinsically linked to the need in many European countries to move from a pay-as-you-go system to funded pension schemes. Transferability of the pay-as-you-go, first pillar is not considered in this lecture3. In addition, exportability - al least for the purpose of this lecture - is limited to services provided by so-called Pension Delivery Organisations (PDOs) ${ }^{4}$, i.e. organisations that provide asset management as well as pension administration services to pension funds. In other words, we do not discuss possible cross-border activities of Dutch and European pension funds, or IORPs5. Neither do we discuss the level playing field (or possible lack of it) in the European Union when considering establishing a pan-European pension fund, but take the regulatory framework in the EU Member States as given.

Some may argue that this lecture is about the international business case of a PDO, under the pretext of academic research. This is partially true. However, there is definitely more at stake, as will become clear. The exportability or transferability of the Dutch model is also intrinsically linked to the future of the Dutch pension system in a European and international context.

First, I will address the unique selling points of the Dutch pension system, in particular of the so-called second pillar. Second, I will define the pension related products that could be exported. Third, I will answer the question why the exportability of the Dutch pension system is still a topical issue, despite the financial crisis. Next, I will give a short overview of the pension landscape in the European Union. Finally, I will present some new research on what we have labelled the transferability of the Dutch pension system to the Member States of the European Union; a joint effort of Alexander Schwan, one of my students, and myself. I will end this lecture with some concluding comments and - last but not least - acknowledgements of the persons that, in one way or the other, have supported me in the process leading to my appointment.

3 Which does not necessarily imply that EU Members States could not adopt elements of the Dutch first pillar, i.e. the AOW (Algemene Ouderdomswet).

4 A term which has been introduced by Keith Ambachtsheer at the DNB/Netspar/loPS Conference, "Frontiers in Pension Finance and Reform", in March 2007.

5 Institution for Occupational Retirement Provision. 


\section{Unique Selling Points of the Dutch pension system}

The first question that should be addressed in the context of this lecture, is which elements make the Dutch pension system eligible for transferability across the Dutch borders. In other words, what are the Unique Selling Points (USPs) of the Dutch pension system?

Before addressing the USPs it is important to note-as already mentioned in the introduction - that we only focus on the so-called funded pension arrangements, in particular the second pillar. When classifying a country's pension system, a distinction can be made between three or four so-called pillars, in line with the classification introduced by the World Bank (1994). The first pillar comprises pay-as-you go schemes financed by the government (taxes or social security related contributions). The second pillar consists of occupational retirement provisions that are in principle - fully funded and that are linked to the plan participants' occupational status. The third pillar comprises funded schemes that are arranged between a financial institution and an individual person. Participation in third pillar schemes is always voluntary. Sometimes, a distinction is also made between the third and the fourth pillar. Third pillar schemes are facilitated by tax measures; fourth pillar schemes are individual schemes for which no favourable tax regimes are in place. Table 1 below gives an overview of the Dutch pension system, structured in line with the World Bank model.

It is generally acknowledged that a balanced distribution of benefits over the first and the other pillars is to be preferred ${ }^{6}$. Pay-as-you go schemes are in particular vulnerable for demographic developments. Funded schemes, on the other hand, are less susceptible to ageing of the population. However, funded schemes are vulnerable for (high) inflation and financial downturns, eroding the value of the pension savings. In case of pay-as-you-go schemes, inflation is less an issue, as the increase in benefits can be financed by an increase in taxes or public debt, of which the latter can be "inflated away". This also implies that countries with high pension savings have a strong interest in monetary and financial stability, as represented by an independent central bank aiming at price stability. Countries that rely mostly on pay-as-you-go schemes for financing their old-age financial benefits are,

6 In The Netherlands the first pillar provides approximately half of the pension benefits; the other half is provided by the second and third pillar (Börsch-Supan, 2004). 
on the other hand, expected to have a smaller interest in monetary stability. As a matter of fact, against the background of an ageing population and an increased pressure on pay-as-you-go schemes, the authorities of these countries may think they are better off with inflationary monetary policies.

Table 1: Overview of the Dutch pension system

\begin{tabular}{|c|c|c|c|}
\hline & $\begin{array}{l}\text { First pillar } \\
\text { AOW }\end{array}$ & $\begin{array}{l}\text { Second pillar } \\
\text { Occupational } \\
\text { pension funds }\end{array}$ & $\begin{array}{c}\text { Third pillar } \\
\text { Individual pension } \\
\text { arrangements }\end{array}$ \\
\hline Participation & $\begin{array}{l}\text { Mandatory - all } \\
\text { Dutch residents }\end{array}$ & $\begin{array}{l}\text { Mandatory - } \\
\text { all workers at } \\
\text { organisations that } \\
\text { have established an } \\
\text { occupational pension } \\
\text { fund (>90\% of the } \\
\text { workforce) }\end{array}$ & Voluntary \\
\hline Financing & $\begin{array}{l}\text { AOW contribution } \\
\text { and general taxes } \\
\text { (pay-as-you-go) }\end{array}$ & Contribution (funded) & Contribution (funded) \\
\hline Parties involved & $\begin{array}{l}\text { Government, Sociale } \\
\text { Verzekeringsbank and } \\
\text { Dutch residents }\end{array}$ & $\begin{array}{l}\text { Social partners, } \\
\text { pension fund and } \\
\text { individual worker }\end{array}$ & $\begin{array}{l}\text { Financial institution } \\
\text { and individual person }\end{array}$ \\
\hline Tax treatment & $\begin{array}{l}\text { No special } \\
\text { treatment }\end{array}$ & $\begin{array}{l}\text { Contribution rates } \\
\text { are tax deductible (up } \\
\text { to a certain amount) }\end{array}$ & $\begin{array}{l}\text { Contribution rates } \\
\text { are tax deductible (up } \\
\text { to a certain amount) }\end{array}$ \\
\hline Benefits & $\begin{array}{l}\text { Fixed amount, } \\
\text { dependent on (among } \\
\text { other things) marital } \\
\text { status and number of } \\
\text { years resided in The } \\
\text { Netherlands (accrual } \\
\text { rate is } 2 \% \text { per year, } \\
\text { between the age of } \\
15 \text { to } 65 \text { ) }\end{array}$ & $\begin{array}{l}\text { Replacement rate of, } \\
\text { in most cases, } 80 \% \text { of } \\
\text { the average annual } \\
\text { salary over a period of } \\
\text { (a career of) } 40 \text { years, } \\
\text { including the first } \\
\text { pillar benefit (hybrid } \\
\text { DB scheme) (1) }\end{array}$ & $\begin{array}{l}\text { Replacement } \\
\text { rate depends on } \\
\text { contribution and } \\
\text { developments on } \\
\text { financial markets } \\
\text { (DC scheme) }\end{array}$ \\
\hline
\end{tabular}

(1) DB or Defined Benefit schemes are characterised by a pre-defined benefit at the age of retirement; DC or Defined Contribution schemes do not have a pre-defined benefit, but are characterised by a fixed and predefined contribution rate. The benefits at the age of retirement depend, among other things, on financial market developments. 
The focus on the second pillar in this lecture should be seen against the background of the necessity prevailing in many EU Member States to shift from predominantly pay-as-you go systems to supplementary funded pension schemes. So far, most EU countries have relied on pay-as-you go schemes, with the exception of the Nordics, the United Kindom and Ireland, although still to a lesser extent than The Netherlands. Notably some EU countries in Central and Eastern Europe have undertaken major reforms of their pension system, thereby moving to funded schemes. However, in most cases, these reforms imply a shift from pay-as-you go to traditional individual defined contribution arrangements, i.e. third pillar arrangements. In this respect The Netherlands stand out, as the funded pillars are characterised by a predominance of the second pillar, i.e. collectively organised schemes.

There is a host of literature on the advantages of the Dutch funded pension arrangements over similar schemes in other countries. Most of this literature focuses on the benefits of the second pillar, as opposed to the third pillar. A good overview is provided by Steenbeek and Van der Lecq (2007).

First, the Dutch second pillar schemes provide for intergenerational solidarity, which is lacking in third pillar arrangements. Intergenerational solidarity relates to the fact that financial as well as other risks can be shared among generations, i.e. young versus old, and even provides for the possibility to share risks between current plan beneficiaries and unborn future generations. The advantages of intergenerational solidarity are estimated to be substantial?.

A second advantage of Dutch second pillar schemes relates to their cost efficiency related to their efficacy. Pension funds are more efficient than insurance companies in providing similar pension arrangements (Bikker and De Dreu, 2007). This is mainly due to the fact that pension funds are not-for-profit organisations that do not incur marketing costs or have to comply with investors' demand for a specific return on

7 See Bonenkamp et al. (2007) for an overview of the relevant literature. In terms of pension assets, estimates of the benefits of intergenerational risk sharing are in a range of o to $30 \%$, In terms of life cycle income of a generation, benefits are estimated to be $6 \%$. Defined in terms of the certainty equivalent consumption, the welfare gains of collective pension schemes can amount to $4 \%$. 
equity. On average, the costs of pension funds are $0.15 \%$ of the assets; for insurance companies, costs amount to $1.27 \%$ of the assets. In other words, the pension benefit provided by insurance companies is $26 \%$ less, ceteris paribus, than the benefit provided by pension funds. Moreover, larger pension funds are even more cost efficient, as the management of pension schemes very much relies on economies of scale. Large pension funds, like ABP, are eight times as efficient than smaller ones.

Thirdly, participants in (hybrid) DB schemes are not confronted with the so-called conversion risk, contrary to DC plan members. DC plan members are supposed to convert their savings into a life annuity at the age of retirement. The pension benefit originating from this annuity to a large extent depends on the market interest rate at the date of conversion. If the interest rate is high, the plan participant will be able to acquire an annuity providing a relatively high benefit. The opposite is true when interest rates are relatively low. In general terms, a one percentage point lower interest rate implies a drop in pension benefits of approximately $7 \%$. DB plan members are not confronted with this risk, in the sense that the conversion risk is spread out over time among all plan members.

A fourth advantage of the Dutch second pillar should be seen in the context of the so-called behavioural finance literature. A good overview is provided by Van Els et al. (2007) and Van Rooij et al. (2007) The experience with individual DC schemes in, for instance, the United Kingdom and the United States (for the latter, see Munnell and Sunden, 2004) show that DC plan members are often not able to take rational decisions, thereby seriously undermining the efficacy of their plans. It is very often the case that DC plan members save too little, or start saving too late in their careers. The possibility - if it exists - to withdraw pension savings when switching jobs is very often used, notably by low-income plan members (who are to suffer most in case of inadequate pension savings). In addition, in those cases in which plan members have to take the investment decisions themselves, irrational decisions can very often be observed. Plan members do seldom realise that investments need to be rebalanced, or should be switched from risk-bearing to more riskaverse assets when they approach their retirement. Well-known is also the so-called Enron case: Enron plan members of all ages had heavily invested their pensions savings in their own company's stock. Hence, when Enron failed, pension schemes became worthless as well. A good 
example of irrational behaviour is also provided by the early days of the pension reform in Sweden (Cronqvist and Thaler, 2004). Plan members were given the possibility to choose from a large number of investment funds in which they could invest their savings, presented in a catalogue that was provided to all plan members. It appeared that most plan members opted for investment funds that were presented first in the catalogue, as they apparently were not very keen on spending much time on absorbing the full set of information. Finally, DC plan members responsible for their own investment decisions very often seem to suffer from a so-called "home bias", in the sense that most investments are done in domestic stock, very often of sectors they know and companies they are familiar with. In other words, many investment portfolios are not well diversified. Hence, and as also been argued in the behavioural finance literature, plan members are much better of if they can delegate investment decisions to professionals or if they are offered a default option, managed by investment professionals. Indeed, members of Dutch pension funds cannot determine their own asset allocation. The advantages of the opportunity to determine asset allocations individually are - at least according to the proponents of the behavioural finance literature - much smaller than the advantages of having professionals at the pension fund managing the pension fund assets.

Last but not least, it is important to note that participation in Dutch pension funds is mandatory. This key element of the Dutch system has two dimensions. First, individual employees of an organisation are automatically enrolled as plan members, if that organisation has established a pension scheme or is a member of a multi-employer fund. Second, employers that are part of a particular sector are obliged to join under certain circumstances - a multi-employer fund ${ }^{8}$. As a result, more than 90\% of all Dutch workers is in one way or the other participating in a pension scheme. Mandatory participation appears to be one of the corner stones of a successful pension system, providing adequate replacement rates. The drawback of mandatory participation is the lack of choice for individuals and the, at first sight, non-existence of a level playing field between pension funds and other financial institutions. However, the latter appears to be not the case in The Netherlands, as confirmed by the European Court of Justice, as mandatory participation

8 The first dimension is known as the "kleine verplichtstelling" (mandatory employee enrolment); the second as the "grote verplichtstelling" (mandatory employer enrolment). 
is necessary to secure a sufficient degree of collective risk sharing (Drijber, 2007).

Given the advantages of the Dutch second pillar, one might question why the Dutch model has not already been adopted by many countries worldwide. As a matter of fact, the opposite appears to be the case. Pension systems in countries that were similar to the Dutch system, such as in the United States and the United Kingdom, appear to be in retreat. The Dutch (hybrid) DB model can best be depicted as a "DB island in a sea of DC". The Dutch system is increasingly becoming the "odd one out". There are several reasons for this development, some originating from within The Netherlands, other having a global or European background.

First, pension funds have traditionally not been very effective in marketing themselves and branding their own product. Given mandatory participation, there has for quite a long time also been no need for active public relations. The neglect of public relations efforts appears to be the drawback of a not-for-profit orientation and the cost efficiency of pension funds. In addition to poor branding efforts, it can also be questioned whether the interest groups representing the Dutch pension sector have always been effective in their lobby and public relations activities. Indeed, the interests of all pension funds are represented by three separate organisations, all of them having only limited resources compared to the associations representing commercial financial institutions9. Recent efforts to increase cooperation between these organisations should hence be applauded. The incompetence of pension funds to proliferate themselves is inversely matched by the public relations efforts of commercial financial institutions, notably insurance companies, that have increased their efforts to, among other things, question the legitimacy of mandatory pension fund participation in order to increase the share of third pillar arrangements to the detriment of the second pillar. These efforts appear to have antagonised pension funds, making them more effective and successful in defending their case.

The Dutch second pillar also appears to have become more "exotic", as at the global level the importance of the third pillar and/or (hybrid) DC

9 Multi-employerfunds are represented by the "Vereniging van Bedrijfstakpensioenfondsen", company funds by the "Stichting voor Ondernemingspensioenfondsen" and so-called pension funds for professions by the "Unie van beroepspensioenfondsen". 
schemes has gradually increased. There are two reasons for this. First, the "dot com" crisis in 2001 and its resulting impact on the financial position of pension funds worldwide made many companies decide to abandon DB schemes and to switch to individual DC arrangements, either in the context of a pension fund or as part of the third pillar. In addition to financial market developments, companies were also triggered by changes in accounting standards. The so-called IFRS rules require that companies listed on the stock exchange account for their pension assets and liabilities on their respective balance sheet if the pension scheme can be characterised as a DB scheme. This is not necessary for DC schemes, because in that case employees bear all the risks involved (and no longer the company). In 1983 more than 60\% of employees in the United States were member of a DB plan. In 2004, the situation had been completely reversed and more than $60 \%$ of employees participated in an individual DC scheme (Munnell and Sunden, 2004).

Finally, as the Dutch system is becoming more "exotic", international and European legislation and/or regulation is not helping to reverse the trend. A good example in this respect is provided by the discussion on the applicability of Solvency II - the solvency framework for insurance companies in the EU - to pension funds. In particular in 2008 a debate emerged as to whether the EU solvency framework for insurance companies should also apply to pension funds, which would have seriously aggravated the demands pension funds would have to face. Besides insurance companies, that were using this opportunity to lobby for the application of Solvency II to pension funds foremost in order to increase their share of the pension market, not many policy makers or Members of the European Parliament were aware of the consequences application of Solvency II would have on pension funds in the EU. For many of them, extending Solvency II to pension funds fitted very well with the ambitions to protect consumers. They did not realise that pension funds are completely different animals than insurance companies and that treating pension funds as insurance companies would eventually harm consumers' interests (EFRP, 2008). After a successful lobby, both the European Commission and the European Parliament have agreed not to pursue the application of Solvency II to pension funds any further. The same line of reasoning holds for the discussion on the IFRS accounting rules and the so-called Portability Directive, that was designed to increase the portability of pension rights across EU borders. Also in these cases the intentions of policy makers were not necessarily wrong. 
However, and without going too much in details, in both cases the Dutch interests have not been served very well. The fact that The Netherlands is not the point of reference in the EU when it comes to pensions appears to be one of the reasons for these developments.

\section{Exportability of the Dutch pension system}

The USPs of the Dutch second pillar suggest that it might be worthwhile to export the Dutch model "one on one" to other countries, notably to countries which should take steps to reform their pension system. This conclusion would, however, be too simple and too naïve. As indeed argued above, the Dutch model appears to be in retreat. Moreover, it should not be neglected that the Dutch pension system has evolved over time in what it constitutes today, including all kind of peculiarities that may be typical for The Netherlands, but that are not necessarily exportable ${ }^{10}$.

Nevertheless, it is possible to disentangle the Dutch model into a number of products or services that can be provided, also in a more general and international context. As already mentioned before, the focus in this respect is on services to be provided by so-called Pension Delivery Organisations (PDOs), and not so much on pension funds themselves. Indeed, the establishment of pan-European pensions funds, providing pension benefits to employees in several EU Member States, is a different issue and is not discussed here. Figure 1 below gives a stylised overview of the business activities of a PDO, based on the balance sheet of a pension fund.

10 The first pension schemes in The Netherlands were introduced in the 19th century. The foundations of modern pension funds, as we know them today, were laid in the first decades of the 2oth century (ABP, 2007). 
Figure 1: The business model of a PDO

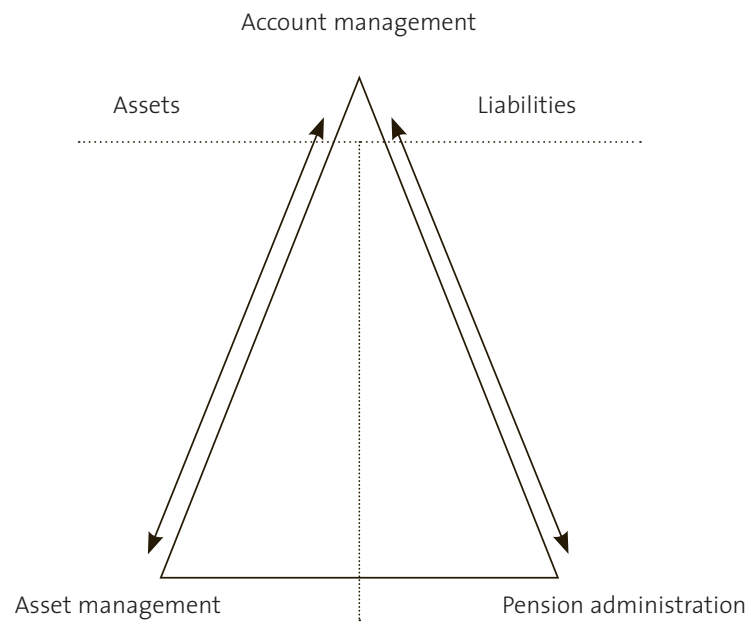

As regards the assets of the pension fund, a PDO typically provides asset management services, either as a fiduciary manager or as a fully-fledged asset manager. Activities include advisory functions, such as asset and liability management, and the formulation of (strategic) investment plans, external manager selection, (internal) asset management, risk management and reporting. As far as the liabilities of the pension fund are concerned, the PDO typically provides administrative services, both to the pension fund as well as to the plan members, communication with respect to the pension rights of plan members, the collection of contributions into the fund as well as the payment of pension benefits. The PDO is also typically involved in accounting and actuarial activities, resulting in reports to the supervisor as well as the funds' annual report. In addition, the PDO may provide advisory functions to the Board of Trustees regarding legal, financial, fiscal and actuarial issues. PDOs may provide services related to both pension funds' balance sheets activities, or only be involved in either asset management or pension administration. Typically, the relationship between the PDO and the pension fund is managed by an account manager or account management team, either organised as a separate function, or as part of the asset management or pension administration functions of the PDO. 
The business concept of a PDO is very much linked to the Dutch pension sector and it is not necessarily the case that these functions can automatically be transferred to an international context. In addition, it is important to distinguish which elements are "typical Dutch", in the sense that PDOs have a competitive advantage in providing these services compared to other (international) service organisations.

Obviously, Dutch PDOs might provide asset management services to pension funds abroad, or to individuals, in case of third pillar products. As a matter of fact, this market appears to rather homogeneous and most players are active at a global scale. The characteristics of the pension deal - DB or DC, collective or individual - are less important; fiscal and legal issues may be relevant, but most asset managers are able to provide tailor-made solutions, also because fiscal and legal isues are often already tackled by providing a harmonised framework at EU level. The value-added of the Dutch PDOs in this respect relates to expertise and costs. Dutch PDOs have a long-standing tradition with respect to pension asset management, which distinguishes them from ordinary asset managers. Asset management linked to pensions typically has to take into account such issues as the duration of the pension liabilities, the ambitions of the fund as well as the desired risk profile. Moreover, Dutch PDOs should be able to distinguish themselves in terms of costs. Given the volume of the assets under management, it should be possible to realise substantial economies of scale. An example of a potentially successful business case in this respect is provided in Box 1 below, outlining the cooperation between APG Group and PensPlan, an Italian PDO.

With respect to pension administration, the situation is more complicated. So far, this business has mainly been locally organised. PDOs that are active in this respect internationally always employ local service providers. The issue is that - so far - it has not been possible to establish a generic pension administration system that can be employed under several jurisdictions. Different from asset management services, legal and fiscal issues appear to be a bottleneck in this respect. To conclude, this market does not appear to be immediately accessible for Dutch PDOs, although the potential is huge. However, this would require large investments in order to make a generic use of pension administration applications possible. 
Box 1: Cooperation between PensPlan and APG Group

PensPlan and APG Group started their collaboration in 2008 as to improve the performance of Italian second pillar pension funds.

By working together with PensPlan, APG Group will contribute to the growth of funded pension schemes in Italy. This is important for Italian citizens because it reduces their dependency on the present pay-as-you-go schemes. From the Dutch perspective it is important that throughout Europe strong funded pension schemes are established that help to finance old-age provisions, thereby implicitly supporting the Dutch second pillar.

As a regional pension administrator in the north of Italy (Trentino-Alto Adige), PensPlan serves a number of Italian pension funds. PensPlan is interested in introducing European best practices to Italy with respect to pension fund asset management, including risk management and control, asset and liability modelling and strategic asset allocation. The cooperation with APG Group offers PensPlan access to the scale and expertise of APG Group in pension asset management.

As a first step of the collaboration APG Group will start to manage own assets of Pensplan (€100 million), from the beginning of 2009 onwards. A rapid growth of assets under management is expected. Moreover, in 2009 an investment structure will be set up for Italian pension funds that are served by PensPlan. As a result, Italian pension funds can profit from the economies of scale and extensive knowhow of APG Group in the fields of pension fund asset management. For this purpose, APG Group aims at establishing an IORP in The Netherlands. The precise modalities of such an IORP are heavily debated in The Netherlands. They could be a means to offer pension schemes in Europe an effective and efficient way to manage assets and liabilities in a balanced way.

It should also be noted that one of the reasons PensPlan and its sponsoring pension funds opted for APG Group is the close link to social partners and the governance of Dutch pension funds. Stakeholders of PensPlan feel comfortable with APG group because of the alignment of the organisation with pension funds and social partners.

Finally, PDOs can become active internationally by providing advisory services. In this respect, Dutch PDOs appear to have a substantial competitive advantage over (foreign) competitors, given their experience and expertise. First, PDOs may advise on the construct and technicalities of the pension deal, both financially as well in terms of governance. Even countries that have opted for 
individual DC schemes can profit from the expertise in terms of financial engineering by establishing so-called "smart" DC schemes that should allow plan members to mimic the results of classic DB schemes, thereby avoiding the pitfalls witnessed in, for instance, the United States. Given their specific expertise, PDOs might also help multinational companies, often responsible for managing pension schemes in many countries, in providing more efficient and effective solutions, for instance by pooling pension assets and liabilities. As a matter of fact, all these advisory services can be regarded as a stepping stone for asset management or, perhaps, pension administration. In other words, although the immediate gains in terms of profit or employment - might be small, they can be the entry ticket to providing fully-fledged pension services.

Table 2 below provides an overview of the services Dutch PDOs might provide in an international context.

Table 2: International services provided by Dutch PDOs

\begin{tabular}{|c|l|l|l|}
\hline Service & \multicolumn{1}{|c|}{ Best practices } & Competitors & \multicolumn{1}{c|}{$\begin{array}{c}\text { Value-added by } \\
\text { Dutch PDOs }\end{array}$} \\
\hline $\begin{array}{c}\text { Asset } \\
\text { management }\end{array}$ & $\begin{array}{l}\text { - ALM and other advisory } \\
\text { services (e.g. fiduciary } \\
\text { management) } \\
\text { - Asset management } \\
\text { - Risk management } \\
\text { - Reporting }\end{array}$ & $\begin{array}{l}\text { - Investment } \\
\text { banks } \\
\text { - Global asset } \\
\text { management } \\
\text { houses }\end{array}$ & $\begin{array}{l}\text { - Cost-efficiency } \\
\text { - Experience with pension } \\
\text { asset management (link to } \\
\text { liabilities and funds' ambitions) } \\
\text { - Involvement of social } \\
\text { partners (governance) }\end{array}$ \\
\hline $\begin{array}{c}\text { Pension } \\
\text { administration }\end{array}$ & $\begin{array}{l}\text { - Collection of contributions } \\
\text { - Administration } \\
\text { - Payment of benefits } \\
\text { - Communication } \\
\text { - Advisory functions (legal, } \\
\text { tax, actuarial) } \\
\text { - Reporting }\end{array}$ & $\begin{array}{l}\text { - Actuarial } \\
\text { service } \\
\text { providers } \\
\text { - Other } \\
\text { providers of } \\
\text { administrative } \\
\text { services }\end{array}$ & $\begin{array}{l}\text { - Potentially large, given the } \\
\text { existing experience and } \\
\text { expertise, but investments } \\
\text { in development of generic } \\
\text { applications are necessary } \\
\text { - Involvement of social } \\
\text { partners (governance) }\end{array}$ \\
\hline $\begin{array}{c}\text { Advisory } \\
\text { functions }\end{array}$ & $\begin{array}{l}\text { - Pension deal construction } \\
\text { - Financial pension } \\
\text { engineering } \\
\text { - Cross-border solutions for } \\
\text { corporates } \\
\text { - Legal, tax, actuarial }\end{array}$ & $\begin{array}{l}\text { - Investment } \\
\text { and actuarial } \\
\text { consultants }\end{array}$ & $\begin{array}{l}\text { - Collective model (even if DC) } \\
\text { - Expertise with respect to } \\
\text { financial pension engineering } \\
\text { - Involvement of social } \\
\text { partners (governance) }\end{array}$ \\
\hline
\end{tabular}


There might - as summarised in Table 2 - also be interest in the experiences in term of governance, in particular the role of social partners as well as the organisation of collective schemes, even if the underlying plan is of a DC nature. First, the Dutch second pillar schemes are based on collective risk sharing, not only in terms of mortality rates and the "classical" risks, but also in terms of intergenerational risk. Similar risk sharing arrangements can also be introduced in DC schemes, at least to some extent. Second, the Dutch (governance) model has contributed to a large degree of flexibility and pragmatism in managing pension schemes. It is relatively easy to adapt pension schemes, as long as social partners agree. For instance, major changes were possible in 2001/2002, after the "dot com" crisis, such as the introduction of conditional indexation. If such flexibility and pragmatism had prevailed in many other countries, such as in the United Kingdom, the demise of DB schemes in these countries might have been prevented".

\section{International ambitions against the background of the financial crisis}

So far, we have concluded that the Dutch pension system avails of a number of USPs making it an attractive export product, despite the fact that the Dutch pension deal can most likely not be exported "one on one" and despite developments that appear to put pressure on, in particular, the second pillar. However, the question arises to which extent the USPS are still valid, given the financial "tsunami" that has also affected the Dutch pension sector ${ }^{12}$. Moreover, is it still appropriate to consider the

"For instance, in the United Kingdom indexation is more or less guaranteed. The fact that this guaranteewas not dropped in the aftermath of the"dot com" crisis, was one of the reasons for the demise of British DB-schemes. As a matter of fact, the United Kingdom is currently considering to introduce conditional indexation in line with The Netherlands.

12 The funding ratio of many pension funds in The Netherlands is close to but lower than 100\% (at least at the end of December 2008), in which case one can technically no longer speak of fully funded pension schemes. It should be noted, though, that the funding ratio strongly depends on the valuation of the liabilities of the pension fund. The Pensioenwet, the relevant Dutch pension legislation, requires pension funds to value the liabilities at "fair value", i.e. by discounting the future pension benefits with risk-free market interest rates, corresponding to the liabilities' duration. However, in other jurisdictions, the regulator accepts valuation of the liabilities at corporate market interest rates or even at expected rates of return on the pension fund's investments. Application of these valuation rules to the Dutch situation would result in much higher funding ratios than currently reported. This aspect seems to be underestimated in some alarming press reports as well: it warrants, in any case, to put some of the conclusions drawn by the press in perspective. 
exportability of the Dutch pension system when Dutch pension funds appear to be in a crisis themselves? Doubts have already been raised - e.g. by the Dutch central bank - with respect to the international ambitions in the area of pensions:

"This future [exporting pension products; ed.] is, from the point of view of the supervisor, not tomorrow. The execution power and motivation of the pension sector should first and foremost focus at addressing the shortfall of pension assets.... Hence, a little bit less attention for marketing and the display window is currently warranted; first, the shop itself should be put in order again."'s(own translation from Dutch).

There are four reasons why, in our view, the international ambitions of the Dutch pension sector should not be put on hold.

First, the focus on the impact of the financial crisis on Dutch pension funds appears to mask the even more pronounced disarray in the area of individual $\mathrm{DC}^{14}$. In other words, the benefits of the Dutch model appear to be even more visible under the current circumstances than one or two years ago. This can be made clear by a stylised example, comparing the Dutch and the US pension systems ${ }^{15}$. Assume two individuals, Jan Modaal (a Dutch employee), and Joe the Plumber (a US worker). Both have reached the respectable age of 65 and are about to receive their first monthly pension benefit. Jan has since his employment been a member of a pension fund that can be characterised as a hybrid DB scheme, the annual accrual of his pension being based on the average salary earned and (wage) indexation being conditional upon the financial position of the pension fund. The accrued benefits represent an annual (gross) pension benefit of

13 See footnote 2. The original text reads "Die toekomst moet wat ons als toezichthouder betreft nog maar even wachten. De kracht en motivatie van ons pensioenveld moet nu eerst ten volle worden ingezet voor de aanpak van de vermogenstekorten ... Even wat minder aandacht voor de marketing en de etalage dus, en eerst de winkel zelf weer goed op orde krijgen".

14 This is illustrated by anecdotic evidence: when visiting the United States early November 2008, many people indicated that they were "too afraid" to open the envelopes containing their 401K statements (which are typically distributed in the autumn).

15 Adapted from a speech delivered by Dick Sluimers, CEO of APG Group, at a conference ("Eye on Pensions) organised by Ernst \& Young on 21 November 2008, "Pension als exportproduct: perspectief vanuit de markt". 
EUR 12,000, including indexation. Joe has been a member of an individual DC plan and avails of assets that, at the eve of his retirement, also represent an annual (gross) pension benefit of EUR 12.000, which would result from converting the assets into a life-long annuity. Now assume the Dutch and US economies are equally affected by a financial crisis that unfolds at the moment Jan and Joe retire. Jan's expected benefit remains the same, i.e. EUR 12.000. Under normal circumstances, these benefits would have been increased to compensate for in increase in wage indexation, e.g. $2.5 \%$. However, as the financial position of the fund has strongly been affected by the crisis, its Board of Trustees decides not to provide any indexation this year. For Joe the situation is completely different. Not only does the financial crisis directly impact the value of his assets (in this example Joe is confronted with a loss of $25 \%$ ), his pension benefits also decrease due to a drop in interest rates (e.g. 0.5 \%-point), resulting in a lower income from the annuity Joe has to acquire. As a result, Joe's expected benefits drop to EUR 8,500 per annum. See also Table 3 below.

Table 3: Impact of the financial crisis on pensions: the case of The Netherlands and the United States

\begin{tabular}{|c|c|c|}
\hline & Jan Modaal (NL) & Joe the Plumber (US) \\
\hline $\begin{array}{l}\text { Impact at age } 65 \\
\text { (at retirement) }\end{array}$ & $\begin{array}{l}\text { - Expected annual pension } \\
\text { benefit before crisis: EUR } \\
\text { 12,000 } \\
\text { - No indexation (2.5\%): EUR } 360 \\
\text { - Expected annual pension } \\
\text { benefit after crisis: EUR 12,000 }\end{array}$ & $\begin{array}{l}\text { - Expected annual pension } \\
\text { benefit before crisis: EUR } \\
\text { 12,000 } \\
\text { - Decrease in stock market } \\
\text { prices (25\%): EUR 3,000 } \\
\text { - Conversion loss (-0.5\%-point } \\
\text { interest rate drop): EUR } 500 \\
\text { - Expected annual pension } \\
\text { benefit after crisis: EUR 8,500 }\end{array}$ \\
\hline $\begin{array}{l}\text { Impact at age } 80 \text { (before the } \\
\text { financial crisis) }\end{array}$ & $\begin{array}{l}\text { - Expected annual pension } \\
\text { benefit: EUR 17,000 }\end{array}$ & $\begin{array}{l}\text { - Expected annual pension } \\
\text { benefit: EUR 12,000 }\end{array}$ \\
\hline $\begin{array}{l}\text { Impact at age } 80 \text { (after the } \\
\text { financial crisis) }\end{array}$ & $\begin{array}{l}\text { - Expected pension benefit: } \\
\text { EUR } 17,000\end{array}$ & $\begin{array}{l}\text { - Expected pension benefit: } \\
\text { EUR 8,500 }\end{array}$ \\
\hline
\end{tabular}

The aforementioned impact of the financial crisis is the result immediately after retirement. Let's now take a look at the pension benefits of Jan and Joe 25 years later, when both have reached their 8oth birthday. Moreover, it is assumed that the financial crisis is a one-off event, with the negative impact on financial markets and the economy gradually wearing off. 
If the financial crisis would not have occurred, Jan would - at the age of 80 - get an annual benefit of EUR 17,000, representing the initial accrual plus wage indexation (2.5\% per annum). Joe would have received EUR 12,000, the same amount as he would have got immediately after his retirement, representing the income from his life-long annuity, that - however - is not indexed to wage or price inflation. After the financial crisis, however, the situation looks completely different. Jan still is expected to receive EUR 17,000 per annum. Although he has missed indexation in the year after retirement, it is assumed that the financial position of the fund improves as the effects of the crisis wear off. Moreover, the advantages of collective risk sharing kick in at this point. Eventually, the pension fund is able to increase the benefits with the indexation that has been foregone in the past. Joe, however, is expected to receive only EUR 8,500 per year, which is half of Jan's pension benefits. Joe had no other choice but to "lock in" the negative impact of the financial crisis on his pension savings when he retired by buying a life-long annuity, paying him EUR 8,500 per year. The only option he would have had to avoid this, is by not having retired at the age of 65 . He then would have worked longer in order to accumulate more pension savings or to wait until the impact of the crisis would have worn off. Actually, it appears that this is exactly what is about to happen in the United States, people more or less being forced to work longer, hoping that the crisis will not last long and that they will keep their jobs ${ }^{16}$.

Second, it should not go unmentioned that a number of Dutch PDOs are closely linked to pension funds and social partners. These PDOs work on the basis of incentives structures that are different from other organisations, in the sense that profit maximisation is not the ultimate goal of shareholders, the said PDOs have a strong interest in supporting the Dutch second pillar and individual incentive structures do not bear similarities with the short-term approaches taken in this respect by many other financial institutions. In other words, the "back to basics" message that appears to penetrate the financial sector worldwide, is already at the foundations of many Dutch PDOs. The time has probably never been so good as now to get this message across.

16 The US Bureau of Labor Statistics estimates that $30 \%$ of the age cohort 65 to 74 will still be working in 2016 as a result of the impact of the financial crisis on individual pensions savings. According to a survey of the AARP (formerly the American Association of Retired Persons), one out of three people being older than 45 years is considering to postpone retirement; one out of five has indicated not having accrued any benefits at all in 2008 . 
Third, as already argued above, the Dutch second pillar is increasingly coming under pressure. It is too early yet to speculate on the possible impact of the financial crisis on the second pillar, but it is evident that there are also structural forces at play that work against collective pension arrangements. By exporting the Dutch knowledge with respect to pensions abroad, thereby focusing on the merits of the Dutch model, it may be possible to strengthen and support the Dutch second pillar. In other words, the exportability of the Dutch pension model also has a strategic dimension that should not be underestimated (see also Adema, 2008).

Finally, besides these strategic considerations also commercial interests are at stake. The Dutch pension market is gradually maturing and Dutch PDOs can only grow by focusing on international markets, or - which may be the case for asset management - try to regain market share that has been lost to foreign institutions. According to projections by the OECD (2007), pension assets are expected to more than double between 2001 and 2012, from approximately USD 15 trillion to more than USD 30 trillion. In addition, the Dutch financial sector is and most likely remains one of the corner stones of the Dutch economy. The Dutch financial industry's contribution to GDP amounts to $7.3 \%$; direct jobs provided by the Dutch financial sector amount to $286.000^{17}$.

That efforts to promote the Dutch pension sector should not be stalled, does not imply that addressing the impact of the financial crisis on Dutch pension funds does not have the highest priority, on the contrary. However, from experience it can be argued that it is not a matter of "or", but of "and". In other words, the international ambitions of PDOs do not necessarily impede on the efforts to put things in order domestically. For instance, and to put things in perspective, the ("core") unit working on international pension solutions at APG Group consists of only a very limited group of persons, at a total of approximately 4,000 staff members.

\section{The European pension landscape}

Before we turn to the transferability of the Dutch model to the EU, it is important to sketch the European pension landscape.

17 Stichting Holland Financial Centre (www.hollandfinancialcentre.com). 
The need for pension reform in the EU is the result of demographic developments and the high reliance on pay-as-you go, or first pillar schemes to finance old-age pensions. Demographic developments are impacted by a decrease in fertility rates and, more importantly, an increase in life expectancy. According to the European Commission (2006), in 2004 a male person in the EU had on average a life expectancy of 75.3 years at birth; women were expected to live for 81.5 years. The most recent Commission projections expect an increase in male life expectancy by 6.3 years (to 81.6 years) and an increase in female life expectancy by 5.1 years up to 86.6 years. As a result of these developments, the so-called old-age dependency ratio, defined as the number of people older than 65 years relative to the potential work force, i.e. people aged between 15 and 64, is expected to increase. In 2003 the old-age dependency ratio of the $25 \mathrm{EU}$ Member States was $24 \%$; it is expected to increase to $51 \%$ in 2050. The impact of these developments on pensions in the EU are clear. First, the number of people eligible for old-age pensions will increase, both in absolute and relative terms. Table 4 below gives an overview of the projected increase in public pension expenditure (as a percentage of GDP) in the EU between 2004 and 2050. As can be seen, for practically all EU Member States an increase in public pension expenditures is expected, on average by $2.5 \%$-point of GDP. Second, financing of this increase in old-age pensions on the basis of current contribution rates will no longer be possible, as the working population will, at least in relative terms, decrease over time.

Without any changes in policy, the increase in public pension expenditures will be a burden for public finances in practically all EU Member States. An increase in budget deficits or public debts can only be avoided by increasing taxes or contribution rates, most likely with a negative impact on economic growth. There are several ways to avert this pensions crisis in the EU and most Member States have embarked on all of the routes described below.

First, efforts can be undertaken to increase the work force - in relative terms - compared to the Commission projections, in order to increase the base for financing pension benefits in the future. The focus in many Member States is on increasing labour participation among female workers, still lagging behind compared to the labour participation among males, and on promoting labour participation of older workers. According to the European Commission (2005a), the employment rate of 
the potential work force is expected to increase from $63.1 \%$ to $70.9 \%$. The female employment rate, though, is expected to increase from only $55.4 \%$ to $65.5 \%$. For older workers, the employment rate is projected to increase from $39.9 \%$ to $58.9 \%$. Measures to increase female and older workers' labour participation may include, among other things, tax measures and measures at promoting the existence and use of child care facilities.

Table 4: Gross public pension expenditure as a percentage of GDP between 2004 and 2050

(Source: European Commission, 2006)

\begin{tabular}{|c|c|c|c|c|c|c|c|c|c|c|c|}
\hline \multicolumn{9}{|c|}{ Public pensions, gross as $\%$ of GDP } & \multirow{2}{*}{$\begin{array}{l}\text { Change } \\
2004-30\end{array}$} & \multirow{2}{*}{$\begin{array}{c}\text { Change } \\
2030-50\end{array}$} & \multirow{2}{*}{$\begin{array}{l}\text { Change } \\
2004-50\end{array}$} \\
\hline Country & 2004 & 2010 & 2015 & 2020 & 2025 & 2030 & 2040 & 2050 & & & \\
\hline $\mathrm{BE}$ & 10.4 & 10.4 & 11.0 & 12.1 & 13.4 & 14.7 & 15.7 & 15.5 & 4.3 & 0.8 & 5.1 \\
\hline $\mathrm{CZ}$ & 8.5 & 8.2 & 8.2 & 8.4 & 8.9 & 9.6 & 12.2 & 14.0 & 1.1 & 4.5 & 5.6 \\
\hline DK & 9.5 & 10.1 & 10,8 & 11.3 & 12.0 & 12.8 & 13.5 & 12.8 & 3.3 & 0.0 & 3.3 \\
\hline $\mathrm{DE}$ & 11.4 & 10.5 & 10.5 & 11.0 & 11.6 & 12.3 & 12.8 & 13.1 & 0.9 & 0.8 & 1.7 \\
\hline EE & 6.7 & 6.8 & 6.0 & 5.4 & 5.1 & 4.7 & 4.4 & 4.2 & -1.9 & -0.5 & -2.5 \\
\hline \multicolumn{12}{|l|}{ GR } \\
\hline ES & 8.6 & 8.9 & 8.8 & 9.3 & 10.4 & 11.8 & 15.2 & 15.7 & 3.3 & 3.9 & 7.1 \\
\hline FR & 12.8 & 12.9 & 13.2 & 13.7 & 14.0 & 14.3 & 15.0 & 14.8 & 1.5 & 0.5 & 2.0 \\
\hline IE & 4.7 & 5.2 & 5.9 & 6.5 & 7.2 & 7.9 & 9.3 & 11.1 & 3.1 & 3.2 & 6.4 \\
\hline IT & 14.2 & 14.0 & 13.8 & 14.0 & 14.4 & 15.0 & 15.9 & 14.7 & 0.8 & -0.4 & 0.4 \\
\hline CY & 6.9 & 8.0 & 8.8 & 9.9 & 10.8 & 12.2 & 15.0 & 19.8 & 5.3 & 7.6 & 12.9 \\
\hline LV & 6.8 & 4.9 & 4.6 & 4.9 & 5.3 & 5.6 & 5.9 & 5.6 & -1.2 & -0.1 & -1.2 \\
\hline LT & 6.7 & 6.6 & 6.6 & 7.0 & 7.6 & 7.9 & 8.2 & 8.6 & 1.2 & 0.7 & 1.8 \\
\hline $\mathrm{LU}$ & 10.0 & 9.8 & 10.9 & 11.9 & 13.7 & 15.0 & 17.0 & 17.4 & 5.0 & 2.4 & 7.4 \\
\hline $\mathrm{HU}$ & 104 & 11.1 & 11.6 & 12.5 & 13.0 & 13.5 & 16.0 & 17.1 & 3.1 & 3.7 & 6.7 \\
\hline MT & 7.4 & 8.8 & 9.8 & 10.2 & 10.0 & 9.1 & 7.9 & 7.0 & 1.7 & -2.1 & -0.4 \\
\hline NL & 7.7 & 7.6 & 8.3 & 9.0 & 9.7 & 10.7 & 11.7 & 11.2 & 2.9 & 0.6 & 3.5 \\
\hline AT & 13.4 & 12.8 & 12.7 & 12.8 & 13.5 & 14.0 & 13.4 & 12.2 & 0.6 & -1.7 & -1.2 \\
\hline PL & 13.9 & 11.3 & 9.8 & 9.7 & 9.5 & 9.2 & 8.6 & 8.0 & -4.7 & -1.2 & -5.9 \\
\hline $\begin{array}{l}T T \\
\end{array}$ & 11.1 & 11.9 & 12.6 & 14.1 & 15.0 & 16.0 & 18.8 & 20.8 & 4.9 & 4.8 & 9.7 \\
\hline SI & 11.0 & 11.1 & 11.6 & 12.3 & 13.3 & 14.4 & 16.8 & 18.3 & 3.4 & 3.9 & 7.3 \\
\hline SK & 7.2 & 6.7 & 6.6 & 7.0 & 7.3 & 7.7 & 8.2 & 9.0 & 0.5 & 1.3 & 1.8 \\
\hline FI & 10.7 & 11.2 & 12.0 & 12.9 & 13.5 & 14.0 & 13.8 & 13.7 & 3.3 & -0.3 & 3.1 \\
\hline SE & 10.6 & 10.1 & 10.3 & 10.4 & 10.7 & 11.1 & 11.6 & 11.2 & 0.4 & 0.2 & 0.6 \\
\hline UK & 6.6 & 6.6 & 6.7 & 6.9 & 7.3 & 7.9 & 8.4 & 8.6 & 1.3 & 0.7 & 2.0 \\
\hline EU-15 ${ }^{1}$ & 10.6 & 10.4 & 10.5 & 10.8 & 11.4 & 12.1 & 12.9 & 12.9 & 1.5 & 0.8 & 2.3 \\
\hline EU-10 & 10.9 & 9.8 & 9.2 & 9.5 & 9.7 & 9.8 & 10.6 & 11.1 & -1.0 & 1.3 & 0.3 \\
\hline EU-12 ${ }^{1}$ & 11.5 & 11.3 & 11.4 & 11.8 & 12.5 & 13.2 & 14.2 & 14.1 & 1.6 & 0.9 & 2.6 \\
\hline EU-25 $^{1}$ & 10.6 & 10.3 & 10.4 & 10.7 & 11.3 & 11.9 & 12.8 & 12.8 & 1.3 & 0.8 & 2.2 \\
\hline
\end{tabular}

Second, obviouslyit is also possible to decrease public pension expenditures by reforming the scheme itself, i.e. by making it less beneficial from the point of view of future beneficiaries. One way of doing this, is to increase the age at which people are eligible for pension benefits, as has recently been decided by the German government ${ }^{18}$. One might also decide to decrease the pension benefits as such, thereby lowering the so-called replacement rate, i.e. the size of the pension benefit relative to the last earned income. Besides the fact that this measure is politically not very popular, it also puts the expected income of elderly people at risk and might increase the poverty risk of this particular group.

18 In Germany it was decided to increase the age of retirement from 65 to 67 years over a period of 24 years: each year the age of retirement will be increased with one month. 
The third group of policy measures aims at increasing so-called private pension savings, either by means of second or third pillar arrangements. The advantage of these policy measures is that future pension benefits become less dependent on demographic developments. Moreover, people will still be able to accrue adequate pension benefits, providing them with a reasonable income after retirement. In other words, replacement rates are not at risk and may even increase over time as savings accumulate. As becomes clear from Figure 2 below, the importance of private pension schemes in the EU is still relatively limited and a lot remains to be done in this respect ${ }^{19}$. On the basis of Table 5 that gives an overview of the development of pension assets in all pension schemes in the EU, similar conclusions can be drawn ${ }^{20}$. It is also clear from Figure 2 and Table 5 that The Netherlands stand out in this respect, both in terms of a high participation of employees in private pension schemes as well as the size of the pension assets as a percentage of GDP. On both accounts, The Netherlands scores highest in the EU.

Figure 2: Percentage of employees contributing to private pension schemes

(Adapted from the European Commission, 2006)

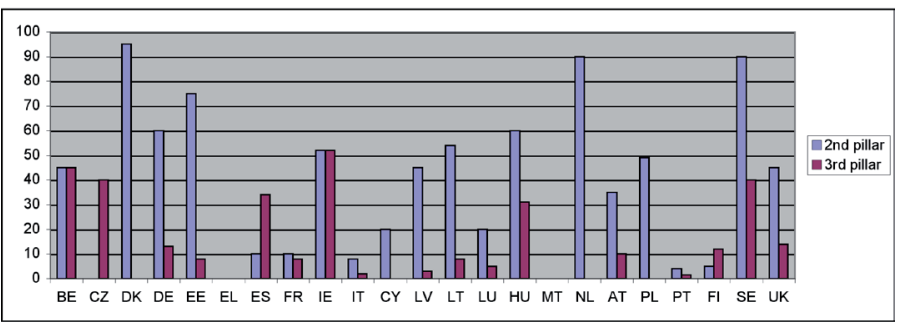

No data for participation in individual schemes are available for Denmark and The Netherlands; for Belgium and Ireland the data refer to both occupational and individual pensions.

19 Please note that Figure 2 only relates to employee participation and not to contribution rates or replacement rates. In order to get a good overview of the benefits from the second and the third pillar, this information should also be taken into account.

20 Please note that Table 5 also includes assets that relate to first pillar provisions, such as earmarked reserve funds. 
Table 5: Assets in all pension schemes, as a \% of GDP

(Source: European Commission, 2006)

\begin{tabular}{|c|c|c|c|c|c|c|c|c|c|c|c|}
\hline \multicolumn{9}{|c|}{ All pensions, assets as \% of GDP } & \multirow{2}{*}{$\begin{array}{c}\text { Change } \\
2004-30\end{array}$} & \multirow{2}{*}{$\begin{array}{l}\text { Change } \\
2030-50\end{array}$} & \multirow{2}{*}{$\begin{array}{l}\text { Change } \\
2004-50\end{array}$} \\
\hline Country & 2004 & 2010 & 2015 & 2020 & 2025 & 2030 & 2040 & 2050 & & & \\
\hline $\mathrm{BE}$ & 4.4 & 7.3 & 13.4 & 16.4 & 13.6 & 1.9 & : & -2.5 & : & : & : \\
\hline $\mathrm{CZ}$ & 0.3 & 3.5 & 6.8 & 9.9 & 11.0 & 9.4 & $:$ & 9.1 & $:$ & $:$ & $:$ \\
\hline DK & $:$ & $:$ & $:$ & : & $:$ & : & $:$ & $:$ & $:$ & $:$ & 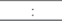 \\
\hline $\mathrm{DE}$ & 0.1 & 0.4 & 0.8 & $:$ & $:$ & $:$ & $:$ & $:$ & : & $:$ & : \\
\hline EE & 2.8 & 9.4 & 15.9 & 25.3 & 37.6 & 50.5 & 76.9 & 101.1 & 47.7 & 50.5 & 98.2 \\
\hline GR & $:$ & $:$ & : & : & : & : & : & : & : & : & : \\
\hline ES & $\therefore$ & : & $\therefore$ & $\therefore$ & $\therefore$ & $\vdots$ & $\therefore$ & $:$ & $\therefore$ & $\therefore$ & $\therefore$ \\
\hline FR & 1.2 & 2.0 & 2.9 & 4.0 & 3.5 & 2.8 & 1.5 & 0.0 & 1.6 & -2.8 & -1.2 \\
\hline IE & 7.3 & 11.1 & 14.4 & 18.1 & 22.5 & 26.0 & 28.3 & 21.9 & 18.7 & -4.1 & 14.6 \\
\hline IT & $:$ & $:$ & $:$ & $:$ & : & $:$ & $:$ & : & : & : & $:$ \\
\hline CY & 39.3 & 39.6 & 39.7 & 37.9 & 33.4 & 25.1 & 1.9 & $:$ & -14.2 & : & : \\
\hline LV & 0.3 & 12.9 & 25.9 & 38.0 & 48.2 & 57.4 & 68.8 & 71.5 & 57.1 & 14.1 & 71.1 \\
\hline LT & 0.3 & 4.3 & 8.6 & 14.0 & 20.7 & 47.9 & 41.5 & 52.7 & 27.6 & 24.8 & 52.4 \\
\hline LU & 23.6 & 31.7 & 37.4 & 39.2 & 32.9 & 17.8 & : & : & -5.8 & $\div$ & : \\
\hline HU & 4.0 & 13.2 & 21.9 & 31.5 & 41.1 & 50.0 & 67.7 & 73.7 & 46.0 & 23.7 & 69.7 \\
\hline MT & : & : & : & : & : & : & : & : & : & : & : \\
\hline NL & 135.5 & 160.6 & 177.5 & 195.6 & 214.5 & 230.1 & 241.0 & 243.7 & 94.6 & 13.6 & 108.1 \\
\hline AT & $:$ & : & : & : & : & : & : & : & : & : & : \\
\hline PL & 7.1 & 15.9 & 24.0 & 33.5 & 42.5 & 51.1 & 69.9 & 85.0 & 44.0 & 34.0 & 78.0 \\
\hline PT & 4.3 & 4.0 & $:$ & $:$ & : & $:$ & : & : & : & $:$ & : \\
\hline SI & 1.4 & 5.5 & 9.6 & 13.9 & 18.3 & 22.6 & 30.1 & 35.9 & 21.3 & 13.3 & 34.5 \\
\hline SK & $:$ & 7.0 & 12.8 & 18.9 & 25.1 & 31.5 & 45.7 & 58.0 & 31.5 & 26.5 & 58.0 \\
\hline FI & 52.4 & 59.3 & 63.1 & 66.0 & 68.2 & 69,9 & 71.3 & 72.9 & 17.5 & 2.9 & 20.5 \\
\hline SE & 38.6 & 53.5 & 60.7 & 66.0 & 69.7 & 72.3 & 68.1 & 60.9 & 33.7 & -11.4 & 22.3 \\
\hline UK & : & $:$ & : & : & : & $:$ & $:$ & : & : & : & $:$ \\
\hline
\end{tabular}

This is precisely where the theme of this lecture comes in, the exportability of the Dutch pension system to the EU. First, The Netherlands are leading other EU Member States with respect to private pension savings. Second, and in the context of this lecture perhaps even more important, The Netherlands are also frontrunner with respect to second pillar pension provisions. Most Member States that have made efforts to increase the size of private pension arrangements in their economies, notably in Central and Eastern Europe, have done so by promoting third pillar (individual) arrangements. However, as already pointed out above, there are serious drawbacks of these arrangements compared to second pillar pension schemes. It is important to note that some of these shortcomings have also been noted in the context of the EU, as can be concluded from a study by the EU Social Protection Committee (2008), of which the highlights are reproduced in Box 2 below. The Social Protection Committee points out in particular the low coverage of many private (voluntary) schemes, which is not likely to be increased by tax measures, the increase in risk-shifting to individuals as well as the poor design of the so-called pay-out phase, which is also a characteristic of individual DC schemes. 
Box 2: Conclusions regarding privately managed pension schemes

(Source: Social Protection Committee, 2008)

\section{HIGHLIGHTS}

- As private pension schemes are now used in a number of Member States to achieve the objectives of adequacy and sustainability, it has become essential to analyse the impact of their development on future pension levels.

- Substantial information gaps, lack of harmonised measures and comparable data. Problem of double counting when assessing coverage levels, leading to biased estimates.

- Great variation in coverage and contribution levels between Member States and schemes: depending on their role within the overall system, low coverage in supplementary pensions (together with breaks in contributions) can become a cause of concern for future adequacy, in particular for the most vulnerable groups (women, young, lover educated, low-paid).

- Tax incentives not likely to be effective in increasing savings levels in voluntary schemes for the whole population.

- Increasing shift of risks (employment, longevity and financial risks) from the pension provider (employer or State) to the individual: there is a need for better financial education, and the impact of career breaks on adequacy need careful consideration.

- Need for careful design of pay-out phase if adequacy to be properly addressed.

- Charges need to be kept low via regulation.

To conclude, demographic developments as well as the current design of pension systems in the EU - with a high reliance on pay-as-you-go schemes - have resulted in an increased need to reform EU pension arrangements. One way of doing so, is to increase the importance of private and funded pension schemes, both in the second and the third pillar. The Dutch experience can be of interest in this respect. Not only because The Netherlands appear to lead the other EU Member States in this context, but also given the relative importance of the second pillar, which - as has been elaborated above - has clear advantages over individual, third pillar 
arrangements. Even though the Dutch system cannot be transferred "oneon-one to the EU", the Dutch experience and expertise in this particular area - the establishment and management of private pension schemes - appears to of interest to other Member States.

\section{Transferability of the Dutch pension system to the European Union}

\section{Methodology}

If indeed an exportable Dutch pension product can be defined and it can still be regarded as desirable to market the Dutch pension system abroad, the next question that arises is, which markets would potentially be fertile grounds for the Dutch pension system. For this purpose a so-called transferability index has been constructed, which attempts to give an indication which Member States of the EU are most susceptible to the introduction of the Dutch pension system. The work done in this area is the result of a joint project with Alexander Schwan. To our knowledge there has been no similar study that analyses which countries may be interesting export markets from the point of view of the Dutch pension system. When reference is made to the Dutch pension system in this context, we refer to the pension deal as it is common in the Dutch second pillar. Hence, no distinction has been made with respect to the individual pension products as defined above (Table 2). However, we will come back to this at the end of this analysis.

The exportability of the Dutch pension system is, in our view, determined by two factors. First, countries that are most susceptible to introducing changes in their pension system are those countries that are facing a large need for pension reform. These are in particular countries in which the current dominant pay-as-you-go old-age pensions are under pressure due to demographic developments. In other words, EU Member States that have to move from pay-as-you-go to funded schemes are potentially interesting export markets. The second factor relates to those elements that make a country susceptible to the peculiarities of the Dutch pension system. Those countries that bear most similarities with the foundations of the Dutch system, in terms of societal, political and social characteristics, should be the ones most susceptible to the Dutch pension system.

Hence, the so-called transferability index comprises two sub-indices: a so-called reform index and a characteristics index. The reform index 
is constructed by taking into account factors that characterise (1) the current (funded) pension scheme in a country as well as those factors that (2) give information about the adequacy and financial sustainability of the pension scheme. The characteristics index is based on factors that provide information regarding (1) the social and political structure of a country, (2) governance and the degree of corporatism in a society ${ }^{21}$ and (3) the state of financial markets and relevant regulation. Figure 3 below gives an overview of the sub-indices that determine the transferability of the Dutch pension system to the European Union.

Figure 3: Overview of the transferability indices

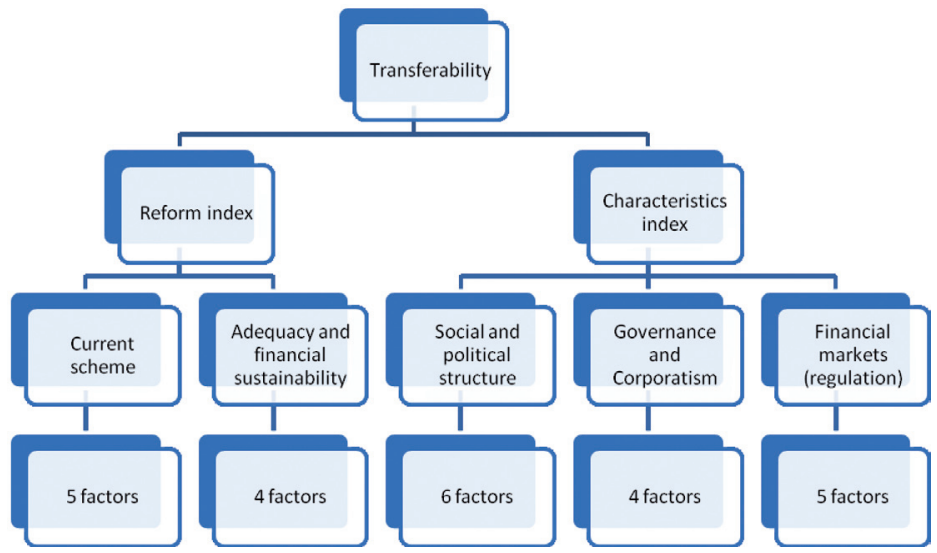

Tables 5 and 6 below give a more detailed overview of all the relevant factors that have been taken into account to construct the sub-indices as well as the relevant sources providing data on these factors. A full description of the relevant factors can be found in the annex.

21 This index mainly measures the involvement of social partners in the economy 
Table 5: Overview of the building stones of the reform index

\begin{tabular}{|c|c|c|}
\hline Factor & Impact on transferability & Data source \\
\hline \multicolumn{3}{|l|}{ Current scheme } \\
\hline Funded scheme coverage & $\begin{array}{l}\text { High coverage - low } \\
\text { transferability }\end{array}$ & European Commission (2006) \\
\hline Adequacy of pension funding & $\begin{array}{l}\text { High adequacy - low } \\
\text { transferability }\end{array}$ & $\operatorname{IMD}(2006)$ \\
\hline DB/DC in funded schemes & DB - higher transferability & SPC (2008) \\
\hline $\begin{array}{l}\text { Mandatory/voluntary } \\
\text { participation }\end{array}$ & $\begin{array}{l}\text { Voluntary - high } \\
\text { transferability }\end{array}$ & SPC (2008) \\
\hline $\begin{array}{l}\text { Social security contribution } \\
\text { level }\end{array}$ & $\begin{array}{l}\text { High level - low - low } \\
\text { transferability }\end{array}$ & IMD (2008) \\
\hline \multicolumn{3}{|c|}{ Adequacy and financial sustainability } \\
\hline Replacement rate projections & High rate - low transferability & Indicator Sub-Group (2006) \\
\hline Old-age poverty risk rate & High risk - high transferability & Eurostat (2008a) \\
\hline Sustainability gap & $\begin{array}{l}\text { High gap - high } \\
\text { transferability }\end{array}$ & European Commission (2008) \\
\hline Sustainability risk & High risk - high transferability & European Commission (2008) \\
\hline
\end{tabular}

Data for Bulgaria, Cyprus, Malta, Latvia and Romania were, unfortunately, not fully available. Hence, these countries were not taken into account when constructing the indices.

In order to construct the indices, all data have been standardised using the linear scaling technique (Salzman, 2003). All factor values have been normalised to the range of $(0,1)$, where $\mathrm{o}$ represents the lowest degree of transferability and 1 the highest. When adding, all factors as well as the sub-indices have been given equal weight, as there is no reason to assume ex ante that some factors or sub-indices should be given more weight than others.

There a number of caveats related to this study that should be mentioned, before discussing the results.

First, this analysis regarding the transferability of the Dutch pension system to the EU countries only considers macro factors and does not take into account micro information that may also be relevant to come to a good judgement as to whether countries are interesting export markets or not. 
Indeed, a proper business case study should also comprise a fully-fledged market analysis (e.g. main players, competitors, etc.). As such, this study is not sufficient to take a decision whether a PDO should enter a particular market. However, it does provide a starting point for such a decision.

Second, the choice of the factors comprising the sub-indices has been based on a normative assessment of both the need for reform as well as the characteristics of the Dutch second pillar schemes. There is no or only little theoretical literature on these issues. Hence, it cannot be claimed that we have covered all relevant factors or that no factor can be omitted. More research is necessary in this respect. In order to ascertain that the factors taken into account provide the intuitively correct results, the sub-indices have also been constructed for The Netherlands themselves. In other words, the results of The Netherlands show whether a factor indeed provides the ex ante expected information. In terms of the reform index, The Netherlands should score low, whereas in terms of the characteristics index, it should score high. This appears to be the case for all factors. As a matter of fact, when defining the factors, we have - for a number of factors related to the characteristics index - first considered the country characteristics as developed by Hofstede (2001). Besides the fact that the Hofstede study does not cover all EU Member States, the results were in many cases counter-intuitive. For instance, The Netherlands scored low on those factors which are regarded as key characteristics for the Dutch pension system (e.g. collectivity). 
Table 6: Overview of the building stones of the characteristics index

\begin{tabular}{|c|c|c|}
\hline Factor & Impact on transferability & Data source \\
\hline \multicolumn{3}{|l|}{ Social and political structure } \\
\hline $\begin{array}{l}\text { Social cohesion priority of } \\
\text { government }\end{array}$ & $\begin{array}{l}\text { High cohesion - high } \\
\text { transferability }\end{array}$ & IMD (2008) \\
\hline $\begin{array}{l}\text { Social responsibility of } \\
\text { business leaders }\end{array}$ & $\begin{array}{l}\text { High responsibility - high } \\
\text { transferability }\end{array}$ & IMD (2008) \\
\hline Intergenerational solidarity & $\begin{array}{l}\text { High solidarity - high } \\
\text { transferability }\end{array}$ & $\begin{array}{l}\text { European Values Survey } \\
(2006)\end{array}$ \\
\hline Political constellation & $\begin{array}{l}\text { Liberal government - low } \\
\text { transferability }\end{array}$ & Own research \\
\hline Financial literacy & $\begin{array}{l}\text { High literacy - low } \\
\text { transferability }\end{array}$ & $\operatorname{IMD}(2008)$ \\
\hline Inflation rate & $\begin{array}{l}\text { High inflation - low } \\
\text { transferability }\end{array}$ & Eurostat (2008b) \\
\hline \multicolumn{3}{|l|}{ Governance and corporatism } \\
\hline $\begin{array}{l}\text { Collective bargaining } \\
\text { coverage }\end{array}$ & $\begin{array}{l}\text { High coverage - high } \\
\text { transferability }\end{array}$ & Visser (2004) \\
\hline $\begin{array}{l}\text { Centralisation of wage } \\
\text { bargaining }\end{array}$ & $\begin{array}{l}\text { High centralisation - high } \\
\text { transferability }\end{array}$ & Visser (2004) \\
\hline Trade union density & $\begin{array}{l}\text { High density - high } \\
\text { transferability }\end{array}$ & Visser (2004) \\
\hline Trust & $\begin{array}{l}\text { High trust - high } \\
\text { transferability }\end{array}$ & $\begin{array}{l}\text { European Commission } \\
(2005 b)\end{array}$ \\
\hline \multicolumn{3}{|l|}{ Financial markets and regulation } \\
\hline Volume pension assets & $\begin{array}{l}\text { High volume - high } \\
\text { transferability }\end{array}$ & CBS (2207); OECD (2007) \\
\hline Stock market capitalisation & $\begin{array}{l}\text { High capitalisation - high } \\
\text { transferability }\end{array}$ & IMD (2008) \\
\hline Capital market accessibility & $\begin{array}{l}\text { High accessibility - high } \\
\text { transferability }\end{array}$ & IMD (2008) \\
\hline $\begin{array}{l}\text { Banking regulations in favour } \\
\text { of business developments }\end{array}$ & $\begin{array}{l}\text { Favourable regulation - high } \\
\text { transferability }\end{array}$ & IMD (2008) \\
\hline $\begin{array}{l}\text { Number of companies listed } \\
\text { on stock exchange (IFRS) }\end{array}$ & $\begin{array}{l}\text { High number - high } \\
\text { transferability }\end{array}$ & IMD (2008) \\
\hline
\end{tabular}


Results

Figure 4 below shows the results for the calculation of the so-called reform index. Countries are grouped with respect to their scores vis-à-vis the average of all countries under consideration.

Figure 4: Results for the reform index

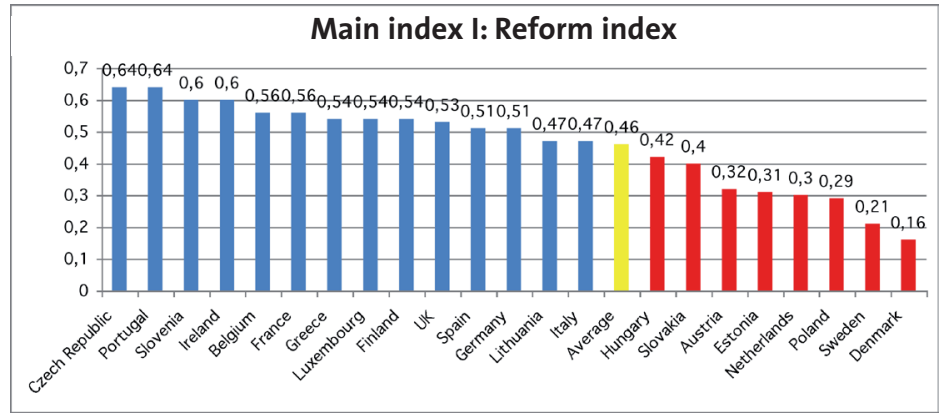

The first group of countries consists of those EU Member States that require reforms in order to increase the sustainability of their pension systems, notably in wake of the demographic developments. These countries score above average and can be regarded as "high transferability" countries, i.e. countries that are deemed to move from pay-as-you-go to funded pension schemes. It is interesting to note that this group comprises, besides the intuitive "usual suspects", also Ireland and the United Kingdom. Ireland scores rather poor in terms of adequacy and financial sustainability of the current schemes. The same holds for the United Kingdom. It appears that in particular in the United Kingdom the changes in the pension system that took place over the past decade were not for the better, on the contrary.

The second group of countries scoring below average comprises EU Member States that are facing a less pressing need for reform. As should be expected, The Netherlands is part of this particular group. This group, maybe surprisingly, also comprises a number of Central and Eastern European countries. These countries are either less affected by demographic developments (e.g. Estonia), or have been rather successful in establishing funded schemes (e.g. Poland), although mostly of a DC nature. By the way, it can be questioned whether the DC schemes 
established in these countries are still adequate after the financial crisis. The impact of the crisis was obviously not taken into account in the data.

Figure 5 below shows the results for the calculation of the so-called characteristics index. Again, countries are grouped with respect to their individual scores vis-à-vis the average of all countries under consideration. The results show an interesting geographical divide, in the sense that the first group - scoring higher than the average - consists of all Western European countries plus Spain, and does not include any of the Central and Eastern EU Member States. Obviously, The Netherlands is part of this group as well. Countries that score very high with respect to this index are, next to The Netherlands, Denmark, Sweden Finland and Austria. These countries do very well in terms of the social and political structure as well as the role of social partners (governance and corporatism). The same holds for France and Belgium, respectively. Luxembourg scores well on the overall index due to its high score in terms of financial markets and regulation.

Figure 5: Results for the characteristics index

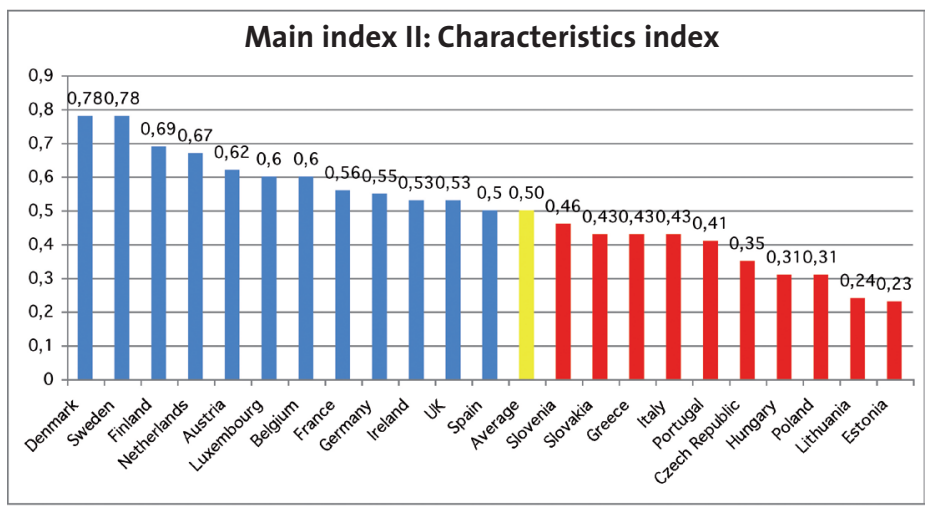

The second group of countries comprises all Central and Eastern European countries as well as most Mediterranean EU Member States. With the exception of Slovenia and Slovakia, all Central and Eastern European countries score poorly in terms of social and political structure; all, with the exception of Slovenia, score also low to very low in terms of governance and corporatism. All score also low on the financial markets and regulation index. As regards the Mediterranean countries, the results are more mixed. These countries score in particular low in terms 
of the financial markets and regulation index as well as with respect to governance and corporatism. However, Greece and Italy score rather high on the social and political structure index.

In order to assess which EU Member States are most susceptible to the Dutch pension system, the results with respect the two indices need to be combined. This is done in Figure 6 below. The black line shows the result of a regression analysis (OLS) that we have done on the scores of the countries under consideration with respect to the two indices. We have found a negative relation between the reform index and the characteristics index, i.e. countries that are confronted with a larger need for reform score lower on the characteristics index. In other words, countries that bear similarities with The Netherlands, in terms of the sub-indices under consideration, are doing better in terms of adequacy and sustainability of their pension schemes.

Figure 6: Transferability

Transferability

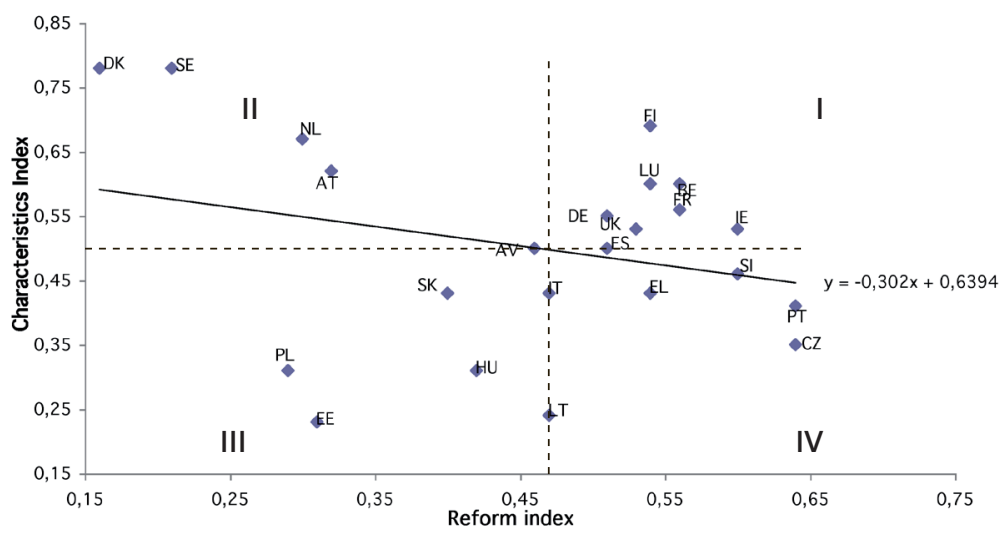

The countries which, according to our analysis, are most susceptible to the Dutch pension system are those countries facing a high need for reform and having similar relevant characteristics as The Netherlands' system (quadrant I of Figure 6). This group includes Belgium, Finland France, Germany, Ireland, Luxembourg, Spain and the United Kingdom. When considering to which EU Member States exporting the Dutch pension system would be most interesting, this is the group to look at first. 
The second group, represented by quadrant II, comprises those countries which have no large demand for reform and are very similar to The Netherlands. As should be the case, The Netherlands is part of this group. Other countries in this group are Austria, Denmark and Sweden. Although the need for drastic changes in their pension systems appears to be limited, these countries might still be interesting to consider in terms of exportability of, in particular, elements of the Dutch pension deal, given their high scores on the characteristics index.

The third group is represented by quadrant IV of Figure 6 These countries are facing a large need for reform of their pension system, but score relatively low on the characteristics index. Countries in this group are the Czech Republic, Greece, Italy, Lithuania, Portugal and Slovenia. Although this group might, at first sight, not be promising in terms of exporting the Dutch pension deal, it should be noted that these countries are interesting to consider when looking at pension asset management as such. For this service, a high similarity with the The Netherlands appears to be less necessary. In other words, when considering the exportability of Dutch pension products and services - as defined previously - both the countries in quadrant I, II as well as quadrant IV deserve the first attention of further analysis and study.

The remaining EU Member States third (quadrant III) are countries that apparently are not facing a great urge to reform their pension system. At the same time, these countries score also very low in terms of similarities with the Dutch system. This group consists of Estonia, Hungary, Poland and Slovakia. These would be countries to stay away from when considering to export to.

There is an another interesting conclusion that can be drawn from Figure $6^{22}$. From the perspective of quadrants I and IV, representing the Member States that should face the largest need for reform, two options for future development exist. One possibility is to move from the said quadrants to quadrant II, i.e. implementing reforms that bring countries closer to the Dutch model. The other possibility is to go in the same direction as a number of Central and Eastern European countries has already gone, i.e. to move to quadrant III, which actually implies moving away from the Dutch

22 It can also be concluded that Figure 6 provides interesting information on potential coalitions with respect to the European policy-making process in the area of pensions. Potential allies of The Netherlands appear to be the countries in quadrants I and II. 
model. Countries that have gone this path have done so rather recently, and have opted for more individual solutions to establish funded pension schemes. As argued above, if not well-designed, the drawbacks of this model can be substantial. Hence, an ambition of Dutch PDOs can also be to provide the right incentives for those countries still in quadrants I and IV, to move to quadrant II. Assuming that EU Member States will indeed realise that they have to reform their pension system and, hence, have to move, but Dutch PDOs would utterly fail in this respect, the Dutch pension system will be even more isolated than it already is. In other words, the exportability or transferability of the Dutch pension system is not only about commercial opportunities; it is intrinsically linked to the future of the Dutch pension system as we know it.

\section{Concluding remarks}

To conclude this lecture I would like to summarise the answers to the questions that I posed in my introductory remarks.

1) What are the unique selling points of the Dutch pension system that make pensions a product worthwhile exporting to the EU?

There is a clear match between the needs of the EU and the experience and the expertise that The Netherlands can offer. Because of demographic developments, public (first pillar) pension systems, which still are the corner stone of pension systems in the EU, will increasingly come under pressure. A pension crisis can be averted by, among other things, increasing the importance of private pension schemes, notably the second and third pillar pension arrangements.

The Netherlands appear to be leading in particular in the area of the management of private pension schemes, notably second pillar arrangements. This leading position can betranslated intoa clear business model, mainlyinthe area of asset management and pension plan design. Pension administration appears to be a less promising proposition, at least at this stage: it requires in any case substantial investments, by Dutch PDOs as well as by PDOs based in other jurisdictions. Dutch PDOs clearly have a competitive edge with respect to cost efficiency, integral pension asset management (in contrast to managing individual mandates) and expertise in the area of governance and pension plan design. All of them are relevant when establishing a more important role for private pension schemes in the EU. 
The transferability of the Dutch pension system is not about exporting the Dutch second-pillar model "one on one" to other EU Member States. This would be too naive. Still, some peculiarities of the Dutch second pillar appear to be of interest for other EU countries and could be taken into account in their pension plan design, in particular as second pillar schemes appear to have a number of advantages over individual, third pillar schemes. Issues that could be taken into account by other Member States relate to (1) governance, and the role of social partners, as to - among other things - increase the participation in private pension schemes and to promote cost-effectiveness of the management of such schemes; and (2) pension plan design, in particular the establishment of an adequate pay-out phase, the establishment of collective schemes, the role of conditional indexation as an important instrument to manage the plan, and financial engineering as to support establishing DC solutions that come closer to the more positive results of DB schemes.

2) Should exporting the Dutch pension system still be a priority under the current circumstances?

The exportability of the Dutch pension system does not only concern a pure business interest. It is also in the interest of The Netherlands to attempt to transfer in particular elements of the second pillar to other EU Member States. The Dutch pension system, although applauded by many, is increasingly becoming under pressure. To some extent, the Dutch pension sector itself can be held responsible for this development, by being too domestically oriented. However, the fact that The Netherlands is increasingly becoming the odd-one out in the area of pensions, should mainly be attributed to external factors, in particular international regulatory developments. By exporting the Dutch model to other EU countries, The Netherlands may be successful in supporting the continued existence of its own model.

As a matter of fact, it can be argued that the time to look across the Dutch borders has never been as topical as currently is the case, contrary to what some argue. First, despite the impact of the financial crisis on Dutch pension funds, pension schemes abroad are in general faring even worse. Indeed, the current circumstances only pronounce the supremacy of second pillar arrangements over third pillar, individual schemes. Second, in particular the Dutch PDOs that are closely linked to pension funds and social partners appear to be in a good position to export their proposition abroad. These PDOs represent the "back to basics" 
philosophy that has seemed to taken hold of the financial industry these days, operating on the basis of a completely different incentive structure than traditional financial institutions.

3) If the business concept to be exported is clear, which EU countries' grounds are most fertile for the Dutch model?

On the basis of two dimensions - the need for reform and the similarities of a country's pension system with the Dutch model - a so-called transferability index has been constructed, which provides more insight in those countries that most susceptible to the Dutch model.

EU Member States that are confronted with a high need for reform while at the same time scoring high in terms of characteristics of their pension system relative to The Netherlands are Belgium, Finland France, Germany, Ireland, Luxembourg, Spain and the United Kingdom. EU Countries that are interesting from the point of view of asset management only are the Czech Republic, Greece, Italy, Lithuania, Portugal and Slovenia. These countries are witnessing a relatively large need for reform - and hence well-managed private pension schemes - but appear to be less susceptible to the Dutch model as a whole. Finally, Austria, Denmark and Sweden appear to be interesting markets as well. Although the need for reform in these countries is relatively small, these EU Member States' pension systems bear the most resemblance to the Dutch system. In other words, doing business with these countries may be relatively easy from a Dutch perspective.

Perhaps most importantly, the research with respect that the transferability index shows that EU Member States have two avenues to go, when reforming their pension system. One is to go in the direction of the Dutch model; the second is to move more into the direction of individual, third pillar schemes. As a matter of fact, those countries that are increasing or recently have successfully increased the importance of private schemes in their jurisdictions - notably Estonia, Hungary, Poland and Slovakia - have all gone this direction. Hence, to avoid full isolation of the Dutch model in the EU, it is important that those countries that still have to undertake major reform efforts, do not choose the individual DC option. Indeed, Dutch PDOs may play an important role in this respect, which is beyond a sole business interest of these institutions. 


\section{Acknowledgements}

Ladies and gentlemen, I am now approaching the end of this lecture, which brings me to the pleasant task of addressing a few words of thanks to the people who have supported me in the process leading up to this appointment at my alma mater.

First, I would like to thank the Executive Board of Maastricht University and my colleagues at the Department of Economics at the Faculty of Economics and Business Administration, in particular Prof. Dr. Joan Muysken and Dr. Tom van Veen. It was actually Tom van Veen who first approached me whether I was interested in an association with the faculty. And without Joan's firm commitment to having a practitioner like myself on board, this appointment would never have taken off. Indeed, I strongly believe in the mutually beneficial relationship between academic institutions and business or policy-makers. Joan and I are in some respects almost opposites, and he is to be praised for acknowledging that it is sometimes very effective to having your counterparts close by. In this respect I have to fill some awfully big shoes, such as those of my predecessor Coen Oort. I would also like to thank Joan for comments on a draft of this lecture. Moreover, I would especially like to thank Alexander Schwan for the joint research that lies at the foundations of this lecture. I'm very proud that he has been accepted as a trainee at the Deutsche Bundesbank in Frankfurt am Main. But also my other academic colleagues, both at the University of Maastricht as well as at other institutions, deserve tribute for the inspiration they provide me.

A special word of thank goes to APG Group, my employer, and in particular Dick Sluimers, its CEO. I would definitely not be standing here without his support. As a matter of fact, it was he who encouraged me to aim for a position of professor at this university, when the Faculty of Economics and Business Administration approached me to institutionalise the relationship that we already had developed for a number of years. Modesty has served me well, but Dick has taught me that overrating this virtue also has its disadvantages. I would also like to thank my colleagues Franka Brouwer for providing the text box on PensPlan, Adri van der Wurff, who is the intellectual source of Figure 1 and who provided valuable comments on a draft of this lecture, and Marina Vizzinisi and Maartje Baltus for their administrative support. Moreover, credits also go to Jurre de Haan, who is responsible for the stylised comparison of the Dutch and US pension system, against the background of the financial crisis. 
Obviously, I would like to thank the people closest to my heart. Admittedly, I'm not always very good in sharing my professional ambitions with those people I care for most. Hence, they often do not realise, and I don't tell them enough, how important they are, in terms of being a stable home and beacon, allowing me to whirl around. I would in particular like to thank Kees; as Joan Muysken is effective in surrounding himself with countervailing powers, Kees is also different from me in many respects, and that's probably why our relationship works out that well. He is my anchor and strongest supporter, never failing in criticizing me when I misbehave. The same goes for my parents, sister and brother-in-law. They taught me what really matters in life and are always good to confront me, when necessary, with a mirror; and I can assure you, it's not always a pretty sight.

There are many people, both in my professional and personal life, that have contributed to what and, more importantly, who I am today, perhaps even without fully realising it themselves. The list is too long to mention; a tribute to them as well.

Finally, I would like to dedicate this lecture to two persons that have a special place in my heart. The first is my grandfather, Caspar Strijthagen, whose name I bear and who died when I was still a little boy. Would he still have lived today, he would probably be the proudest person in this hall. The second person is my niece, Anna Vogelzang, who bears my name, and which fills me with pride. She is still too young to grasp an occasion like this, but I hope she will be proud of her uncle once, long after I am gone.

Ik heb gezegd. 


\section{Literature}

ABP (2007), ABP at 85 , Heerlen.

Adema, Y. (2008), The international spillover effects of ageing and pensions, PhD Thesis, Tilburg University.

Bikker, J.A and J. de Dreu (2007), Operating costs of pension schemes, in: Steenbeek, O. and S.G. van der Lecq, Costs and Benefit of Collective Pension Systems, Springer Verlag, Berlin/Heidelberg.

Bonenkamp, J.P.M., Van de Ven, M.E.A.J. and E.W.M.T. Westerhout (2007), in: Steenbeek, O. and S.G. van der Lecq, Costs and Benefit of Collective Pension Systems, Springer Verlag, Berlin/Heielberg.

Börsch-Supan, A. (2004), Mind the gap: the effectiveness of incentives to boost retirement saving in Europe, Mannheimer Forschungsinstitut Ökonomie und Demographischer Wandel, Juni 2004.

CBS (2007), Dutch pension provisions highest in Europe, Web Magazine, 20th December 2007, The Hague.

Cronqvist, H. and R.H. Thaler (2004), Design choices in privatised socialsecurity systems: learning from the Swedish experience, American Economic Association Papers and Proceedings, pp. 424-428.

Drijber (2007), Modernisering van het Uitvoeringsmodel voor Pensioenregelingen; grenzen en mogelijkheden vanuit mededingsrechtelijk en Europeesrechtelijk perspectief, rapport uitgebracht aan het Ministerie van Sociale Zaken en Werkgelegenheid, 22 maart 2007.

European Federation for Retirement Provision (2008), IORP Directive - securing workplace pensions, EFRP Paper on Funding and Solvency Principles for IORPs, Brussels, May 2008.

European Commission (2005a), The 2005 EPC projections of age-related expenditures (2004-2050) for the EU25 Member States: underlying assumptions and projection methodologies, European Economy Reports and Studies, no. 4. Brussels. 
European Commission (2005b), Special Eurobarometer no. 223, Social Capital, February 2005, Brussels.

European Commission (2006), Adequate and sustainable pensions, Synthesis Report, Brussels.

European Commission (2008), Public Finances in EMU: 2008, European Economy X/2008, Brussels.

European Values Survey (2006), European Values Study, Tilburg University, Faculty of Social and Behavioural Sciences.

Eurostat (2008a), At the risk of poverty rate, Structural Indicators, Brussels.

Eurostat (2008b), Economic Indicators, Brussels.

Hofstede, G.H. (2001), Culture's consequences: comparing values, behaviours, institutions, and organisations across nations, 2nd edition, Sage Publications, Thousand Oaks/London/New Delhi.

IMD (2008), World Competitiveness Yearbook 2008, www.worldcompetiteviness.com.

Munnel, A.H. and A. Sunden (2004), Coming Up Short: The Challenge of 401(k) Plans, The Brookings Press, Washington DC.

OECD (2007), Pensions at a Glance, Public Policies Across EU Countries, 2007 Edition, Paris.

Salzman,J.(2003), Methodological Choices Encountered in the Construction of Composite Indices of Economic and Social Well-Being, Center for the Study of Living Standards, Ottawa.

Social Protection Committee (2008), Privately managed funded pension provision and their contribution to adequate and sustainable pensions, Brussels.

Steenbeek, O. and S.G. van der Lecq (2007), Costs and Benefits of Collective Pension Systems, Springer Verlag, Berlin/Heidelberg. 
Van Els, P.J.A., van Rooij, M.C.J. and M.E.J. Schuit (2007), Why mandatory retirement saving? in: Steenbeek, O. and S.G. van der Lecq, Costs and Benefits of Collective Pension Systemss, Springer Verlag, Berlin/ Heidelberg.

Van Rooij, M.C.J., Kool, C.J.M. and H.M. Prast (2007), Risk-return preferences in the pension domain: are people able to choose?, Journal of Public Economics, no. 91, pp. 701-722.

Visser, J. (2004), Patterns and variations in European industrial relations, in: European Commission, Industrial Relations in Europe 2004, Brussels, 2004.

World Bank (1994), Averting the Old-Age Crisis: Policies to Protect the Old and Promote Growth, A World Bank Policy Research Report, Washington DC. 


\section{Annex: Full description of the transferability index factors}

Reform index: current scheme

- Funded scheme coverage: represented by the percentage of employees contributing to private funded schemes (both 2nd and 3rd pillar). It is assumed that countries where coverage levels are higher are confronted with a lower need for reform, and hence score lower in terms of transferability,

- Perceived adequacy of pension funding: represents the perceived adequacy of pension funding by the public in a particular country. High adequacy is associated with little need for reform and low transferability.

- $D B$ or $D C$ : it is assumed that countries where DB schemes are most prominent have less demand for reform (and hence face lower transferability) than countries where DC schemes are highly prevalent.

- Mandatory of voluntary: it is assumed that countries where participation in pension schemes is (partially) mandatory have less need to reform their systems (and hence score lower on transferability) than countries where participation is voluntary.

- Social security contribution level: it is assumed that countries where the difference between gross and net salaries is already rather substantial (i.e. high social security contributions) have less leeway in establishing funded schemes. Hence, transferability is lower.

Reform index: adequacy and financial sustainability

- Replacement rate (projections up to 2050): countries which are expected to have low replacement rates have a higher need for reform, and hence score better in terms of transferability.

- Old-age povertyriskrateaftersocialtransfers: it is assumed thatcountries where the old-age poverty risk is highest after social transfers have a higher need for pension reform. Hence, transferability is higher.

- Sustainability gap: represented by computations by the European Commission addressing to which extent public finances in EU Member States are to come under pressure due to demographic developments. A large sustainability gap represents a higher need for reform and higher transferability.

- Sustainability risk: represented by computations by the European Commission addressing the risk to which extent public finances 
in EU Member States are to come under pressure due to demographic developments. A large sustainability risk represents a higher need for reform and higher transferability.

\section{Characteristics index: social and political structure}

- Social cohesion priority of government: represents the importance attached by the government with respect to social cohesion. A high score represents high transferability.

- Social responsibility of business leaders: countries where the social responsibility of business leaders is high are assumed to avail of employers and employers' organisations that give importance to negotiations with trade unions as well as an adequate pension scheme. A high score is associated with high transferability.

- Intergenerational solidarity: measures to which extent the population of a particular countries values intergenerational solidarity. A high score is associated with high transferability.

- Political constellation: the Dutch model is assumed to thrive most in a centre-left orcentre-right political environment.A social democrat or left-wing government may be more conducive to the first pillar, state promoted pension scheme. However, worst condition - in terms of transferability - is the existence of a right-wing or liberal government, which is assumed to promote individual DC schemes.

- Financial literacy: countries where people score high in terms of literacy may be best equipped to take care of their pensions themselves, hence these countries score low in terms of transferability. The opposite may be true for countries where literacy is low.

- Inflation rate: inflation is the key enemy of funded schemes. The inflation rate in countries represents the degree of inflation aversion in that country. High inflation rates do not match very well with funded schemes, and vice versa. Hence, high inflation rates are associated with low transferability.

\section{Characteristics index: governance and corporatism}

- Collective bargaining: represents the importance of collective bargaining between social partners in an economy. It is assumed that a high degree of collective bargaining is associated with a high degree of transferability. 
- Centralisation of wage bargaining: represents the degree of centralised power of social partners. A high degree of centralisation is associated with a high degree of transferability.

- Trade union density: represents the importance of trade unions in a particular country. A high trade union density is assumed to be associated with a high degree of transferability.

- Trust: measures the degree of trust in authorities, or institutions and organisations to which authority has been delegated. A high degree of trust is assumed to be associated with high transferability. The Dutch model assumes high trust in the civil society and organisations like employees' and employers' organisations, as opposed to countries where there is low trust in official authorities and organisations and citizens prefer to have a high degree of individual freedom.

\section{Characteristics index: financial markets and regulation}

- Volume of pension assets: countries with high pensions savings are assumed to have both well-functioning capital markets as well as the relevant knowledge with respect to asset management. A high score on this factor is associated with high transferability.

- Stock market capitalisation: represents the degree of development of the local capital market. A high stock market capitalisation is to be assumed to correlate with high transferability. It should be noted, however, that pension funds - in any case in The Netherlands invest a substantial part of their assets across their national borders. In other words, the value-added of this factor should not be overstated.

- Capital market accessibility: measures the degree of capital market development as perceived by companies and financial institutions. A high degree of accessibility is assumed to be associated with high transferability.Thesamecaveatasmentionedaboveappliestothisfactor.

- Banking regulations in favour of business developments: measures the degree to which companies and financial institutions perceive banking regulations in a country to be conducive to business developments. A high score is assumed to be associated with high transferability.

- Number of listed companies on the stock exchange: this factor is included to give expression of the likely importance of IFRS accounting rules with respect to pensions in a country. Listed companies are expected to comply with these IFRS rules that, among other things, imply that companies have to include pension 
assets and liabilities - in case of a DB scheme - on their balance sheets. The larger the number of listed companies, the more substantial this problem will be. Switching to the Dutch pension system, i.e. notably the establishment of so-called multi-employer pension funds, would alleviate this problem, as the pension assets and liabilities of these funds do not have to be attributed to individual companies. Multi-employer funds may be treated as DC schemes, implying that only contributions in the fund have to be accounted for. In other words, a high score on this factor - the number of listed companies on the stock exchange - is assumed to be associated with high transferability. 
